\title{
Jannaschia donghaensis sp. nov., isolated from seawater of the East Sea, Korea
}

\author{
Jung-Hoon Yoon, So-Jung Kang, Sooyeon Park and Tae-Kwang Oh \\ Korea Research Institute of Bioscience and Biotechnology (KRIBB), PO Box 115, Yusong, Taejon, \\ Korea
}

Correspondence

Jung-Hoon Yoon

jhyoon@kribb.re.kr

\begin{abstract}
A Gram-negative, non-motile and rod-, oval- or coccoid-shaped strain, DSW-17 ${ }^{\top}$, was isolated from seawater of the East Sea, Korea, and subjected to a polyphasic taxonomic study. Strain $\mathrm{DSW}-17^{\top}$ grew optimally at $\mathrm{pH} 7.0-8.0$ and $25^{\circ} \mathrm{C}$. It contained $\mathrm{Q}-10$ as the predominant ubiquinone and $\mathrm{C}_{18: 1} \omega 7 \mathrm{c}$ as the major fatty acid. Major polar lipids were phosphatidylcholine, phosphatidylglycerol, phosphatidylethanolamine and an unidentified glycolipid. The DNA G + C content was 65.2 mol\%. Phylogenetic analysis based on 16S rRNA gene sequences showed that strain DSW $-17^{\top}$ was phylogenetically most closely affiliated to the genus Jannaschia. Strain DSW $-17^{\top}$ exhibited $16 \mathrm{~S}$ rRNA gene sequence similarity values of $96.5 \%$ with the type strains of three recognized species of the genus Jannaschia. DNA-DNA relatedness data and differential phenotypic properties, together with the phylogenetic distinctiveness, demonstrated that strain DSW $-17^{\top}$ is distinguishable from the recognized species of the genus Jannaschia. On the basis of phenotypic, phylogenetic and genetic data, strain DSW-17 $7^{\top}$ was classified in the genus Jannaschia as a member of a novel species, for which the name Jannaschia donghaensis sp. nov. is proposed. The type strain is DSW $-17^{\top}\left(=\mathrm{KCTC} 12862^{\top}=\mathrm{JCM} 14563^{\top}\right)$.
\end{abstract}

The genus Jannaschia was created by Wagner-Döbler et al. (2003) with the description of a single species, Jannaschia helgolandensis. Three further species of the genus have been described subsequently, Jannaschia cystaugens (Adachi et al., 2004), Jannaschia rubra (Macián et al., 2005) and Jannaschia seosinensis (Choi et al., 2006). However, Jannaschia cystaugens was reclassified as a synonym of Thalassobacter stenotrophicus by Pujalte et al. (2005). Phylogenetic analyses based on 16S rRNA gene sequences have shown that the genus Jannaschia falls within the class Alphaproteobacteria (Wagner-Döbler et al., 2003; Choi et al., 2006). In this study, we report the taxonomic characterization of a Jannaschia-like bacterial strain, DSW$17^{\mathrm{T}}$, which was isolated from seawater off Dokdo in the East Sea, Korea.

Seawater collected from the coast of Dokdo in the East Sea, Korea, was used as the source for the isolation of novel bacterial strains. Strain DSW $-17^{\mathrm{T}}$ was isolated by means of the standard dilution plating technique at $25{ }^{\circ} \mathrm{C}$ on marine agar 2216 (MA; Difco). The type strains of three species of the genus Jannaschia were used as reference strains for DNA-DNA hybridization. Cultures of J. helgolandensis DSM $14858^{\mathrm{T}}$ and J. rubra DSM $16279^{\mathrm{T}}$ were obtained from the Deutsche Sammlung von Mikroorganismen und Zellkulturen (DSMZ), Braunschweig, Germany. J. seosinensis

Abbreviation: TEM, transmission electron microscopy.

The GenBank/EMBL/DDBJ accession number for the $16 \mathrm{~S}$ rRNA gene sequence of strain DSW-17 $7^{\top}$ is EF202612.
KCCM $42114^{\mathrm{T}}$ was obtained from the Korean Culture Center of Microorganisms (KCCM), Seoul, Korea. The morphological, physiological and biochemical characteristics of strain DSW-17 $7^{\mathrm{T}}$ were investigated using routine cultivation on MA at $25^{\circ} \mathrm{C}$.

Cell morphology was examined by light microscopy (E600; Nikon) and transmission electron microscopy (TEM). Flagellation was determined by TEM (CM-20; Philips) with cells from exponentially growing cultures. Cells were negatively stained with $1 \%(\mathrm{w} / \mathrm{v})$ phosphotungstic acid and the grids were examined after being air-dried.

Growth under anaerobic conditions was determined after incubation in a Forma anaerobic chamber on MA and MA supplemented with nitrate, both of which had been prepared anaerobically using nitrogen. Growth in the absence of $\mathrm{NaCl}$ was investigated using trypticase soy broth prepared according to the formula of the Difco medium except that $\mathrm{NaCl}$ was excluded. Growth at various $\mathrm{NaCl}$ concentrations was investigated in marine broth 2216 (MB; Difco) or trypticase soy broth (Difco). Growth at various temperatures $(4,10,15,20,22,25,28,30,31,32,33,34,35$ and $40{ }^{\circ} \mathrm{C}$ ) was measured on MA. Growth on trypticase soy agar (TSA; Difco), nutrient agar (NA; Difco) and MacConkey agar (Difco) was tested at $25{ }^{\circ} \mathrm{C}$. Catalase and oxidase activities and hydrolysis of casein, starch and Tweens 20, 40, 60 and 80 were determined as described by Cowan \& Steel (1965). Hydrolysis of hypoxanthine, tyrosine and xanthine was tested on MA using the substrate 
concentrations described by Cowan \& Steel (1965). Hydrolysis of aesculin, gelatin and urea and nitrate reduction were investigated as described previously (Lanyi, 1987) with the modification that artificial seawater was used for the preparation of media. The artificial seawater contained $\left(1^{-1}\right.$ distilled water) $23.6 \mathrm{~g} \mathrm{NaCl}, 0.64 \mathrm{~g}$ $\mathrm{KCl}, 4.53 \mathrm{~g} \mathrm{MgCl}_{2} .6 \mathrm{H}_{2} \mathrm{O}, 5.94 \mathrm{~g} \mathrm{MgSO}_{4} \cdot 7 \mathrm{H}_{2} \mathrm{O}$ and $1.3 \mathrm{~g}$ $\mathrm{CaCl}_{2} \cdot 2 \mathrm{H}_{2} \mathrm{O}$ (Bruns et al., 2001). $\mathrm{H}_{2} \mathrm{~S}$ production was tested as described previously (Bruns et al., 2001).

Susceptibility to antibiotics was investigated on MA plates by using discs containing the following concentrations of antibiotic; $100 \mathrm{U}$ polymyxin $\mathrm{B}, 50 \mu \mathrm{g}$ streptomycin, $20 \mathrm{U}$ penicillin $\mathrm{G}, 100 \mu \mathrm{g}$ chloramphenicol, $10 \mu \mathrm{g}$ ampicillin, $30 \mu \mathrm{g}$ cephalothin, $30 \mu \mathrm{g}$ gentamicin, $5 \mu \mathrm{g}$ novobiocin, $30 \mu \mathrm{g}$ kanamycin, $30 \mu \mathrm{g}$ neomycin, $15 \mu \mathrm{g}$ oleandomycin, $100 \mu \mathrm{g}$ carbenicillin and $30 \mu \mathrm{g}$ tetracycline. Acid production from carbohydrates was tested as described by Leifson (1963) with the modification that artificial seawater was used. Utilization of various substrates for growth was determined as described by Baumann \& Baumann (1981), using supplementation with $2 \%(\mathrm{v} / \mathrm{v})$ Hutner's mineral salts solution (Cohen-Bazire et al., 1957) and 1\%(v/v) vitamin solution (Staley, 1968), and by Yurkov et al. (1994). Other physiological and biochemical tests were performed with the API 20E and API ZYM systems (bioMérieux). For in vivo pigment-absorption spectrum analysis, strain DSW $-18^{\mathrm{T}}$ was cultivated aerobically in the dark at $25{ }^{\circ} \mathrm{C}$ in $\mathrm{MB}$. The culture was washed twice by centrifugation using a MOPS buffer (MOPS, $0.01 \mathrm{M}$ $\mathrm{NaOH}, 0.1 \mathrm{M} \mathrm{KCl}, 0.001 \mathrm{M} \mathrm{MgCl}_{2} ; \mathrm{pH}$ 7.5) and disrupted by sonication (Sonifier 450; Branson). After removal of cell debris by centrifugation, the absorption spectrum of the supernatant was examined on a spectrophotometer (DU800; Beckman Coulter).

Cell biomass for DNA extraction and for isoprenoid quinone and polar lipid analyses was obtained from cultivation in $\mathrm{MB}$ at $25{ }^{\circ} \mathrm{C}$. Chromosomal DNA was isolated and purified according to the method described by Yoon et al. (1996), with the exception that RNase T1 was used in combination with RNase A to minimize the contamination of RNA. The 16S rRNA gene was amplified by PCR using two universal primers, 5'-GAGTTTGATCCTGGCTCAG- $3^{\prime}$ and $5^{\prime}$-AGAAAGGAGGTGATCCAGCC-3', as described previously (Yoon et al., 1998). Sequencing of the amplified 16S rRNA gene and phylogenetic analysis were performed as described by Yoon et al. (2003).

Isoprenoid quinones were analysed according to Komagata \& Suzuki (1987) using reversed-phase HPLC. Polar lipids were extracted using the procedures described by Minnikin et al. (1984) and were identified by two-dimensional TLC followed by spraying with appropriate detection reagents (Minnikin et al., 1984; Komagata \& Suzuki, 1987). The presence of phosphatidylcholine was confirmed by spraying with Dragendorff's reagent (Sigma). For cellular fatty acid analysis, cell mass of strain DSW $-17^{\mathrm{T}}$ was harvested from MA plates after cultivation for 7 days at $25{ }^{\circ} \mathrm{C}$. The fatty acids were extracted and fatty acid methyl esters were prepared according to the standard protocol of the MIDI/ Hewlett Packard Microbial Identification System (Sasser, 1990).

The DNA G + C content was determined by the method of Tamaoka \& Komagata (1984) with a modification that DNA was hydrolysed using nuclease P1 (Boehringer Mannheim) and the resultant nucleotides were analysed by reversed-phase HPLC. DNA-DNA hybridization was performed fluorometrically by the method of Ezaki et al. (1989) using photobiotin-labelled DNA probes and microdilution wells. Hybridization was performed with five replications for each sample. The highest and lowest values obtained in each sample were excluded and the means of the remaining three values were quoted as DNADNA relatedness values.

The morphological, cultural, physiological and biochemical characteristics of strain DSW $-17^{\mathrm{T}}$ are given in the species description (see below) or are shown in Table 1. Strain DSW $-17^{\mathrm{T}}$ did not produce bacteriochlorophyll $a$ aerobically in the dark. The sonicated in vivo cell extracts of strain DSW $-17^{\mathrm{T}}$ showed no absorption maximum between 400 and $1000 \mathrm{~nm}$. The almost complete 16S rRNA gene sequence of strain DSW- $17^{\mathrm{T}}$ determined in this study comprised 1422 nucleotides, representing approximately $96 \%$ of the Escherichia coli 16S rRNA gene sequence. Comparative 16S rRNA gene sequence analysis revealed that strain DSW $-17^{\mathrm{T}}$ was most closely related to the genus Jannaschia. In the phylogenetic tree based on the neighbour-joining algorithm, strain DSW- $17^{\mathrm{T}}$ joined the clade comprising species of the genus Jannaschia with a bootstrap resampling value of $95.4 \%$ (Fig. 1). The same tree topology was also found in the trees based on the maximum-likelihood and maximum-parsimony algorithms (Fig. 1). Strain DSW-17 ${ }^{\mathrm{T}}$ exhibited $16 \mathrm{~S}$ rRNA gene sequence similarity values of $96.5 \%$ to all of three recognized species of the genus Jannaschia and of less than $95.3 \%$ to other species used in the phylogenetic analysis.

The predominant isoprenoid quinone detected in strain DSW- $17^{\mathrm{T}}$ was ubiquinone-10 (Q-10) at a peak area ratio of approximately $95 \%$. Major polar lipids found in strain DSW $-17^{\mathrm{T}}$ were phosphatidylcholine, phosphatidylglycerol, phosphatidylethanolamine and an unidentified glycolipid. The polar lipid profile of DSW- $17^{\mathrm{T}}$ was distinguishable from that of J. helgolandensis in that diphosphatidylglycerol was absent (Wagner-Döbler et al., 2003). The fatty acid profile of strain DSW- $17^{\mathrm{T}}$ contained large amounts of unsaturated and straight-chain fatty acids; the major component $\left(>10 \%\right.$ of total fatty acids) was $\mathrm{C}_{18: 1} \omega 7 \mathrm{c}$ (Table 2). This fatty acid profile was similar to those of recognized species of the genus Jannaschia, although there were differences in the proportions of some fatty acids, particularly $\mathrm{C}_{19: 0}$ and cyclo $\mathrm{C}_{19: 0} \omega 8 \mathrm{c}$. These differences may result from variations in cultivation conditions and 
Table 1. Differential phenotypic characteristics of Jannaschia donghaensis sp. nov. and other species of the genus Jannaschia

Species: 1, J. donghaensis sp. nov.; 2, J. helgolandensis (data from Wagner-Döbler et al., 2003; Choi et al., 2006); 3, J. rubra (Macián et al., 2005; Choi et al., 2006); 4, J. seosinensis (Choi et al., 2006). +, Positive; -, negative; w, weakly positive; ND, not determined. Data in parentheses are for the type strain. All species are positive for catalase (not determined for J. rubra). All species are negative for Gram-staining and hydrolysis of urea (not determined for J. rubra).

\begin{tabular}{|c|c|c|c|c|}
\hline Characteristic & 1 & 2 & 3 & 4 \\
\hline Cell shape & Pleomorphic & Irregular rods & Rods & Rods \\
\hline Cell length $(\mu \mathrm{m})$ & $0.6-5.0$ & $1.9-3.2$ & $1.0-2.0$ & $1.1-2.3$ \\
\hline Cell diameter $(\mu \mathrm{m})$ & $0.5-2.5$ & $0.7-1.1$ & 0.5 & $0.7-1.2$ \\
\hline Motility & - & - & + & + \\
\hline Colony colour & Strong orange & White & Red & Dark red \\
\hline Maximum growth temperature $\left({ }^{\circ} \mathrm{C}\right)$ & 32 & 30 & 25 & 35 \\
\hline Optimum temperature for growth $\left({ }^{\circ} \mathrm{C}\right)$ & 25 & $25-30$ & $20-25$ & $30-35$ \\
\hline Oxidase & + & W & + & - \\
\hline Nitrate reduction to nitrite & - & - & - & + \\
\hline \multicolumn{5}{|l|}{ Hydrolysis of: } \\
\hline Aesculin & - & - & $\mathrm{ND}$ & + \\
\hline Gelatin & - & - & - & + \\
\hline Starch & - & - & - & + \\
\hline Tween 80 & $\mathrm{w}$ & - & - & - \\
\hline \multicolumn{5}{|l|}{ Utilization of: } \\
\hline Cellobiose & - & + & - & - \\
\hline Citrate & - & + & $\mathrm{w}$ & - \\
\hline D-Fructose & - & + & + & - \\
\hline Galactose & - & + & + & ND \\
\hline D-Glucose & - & + & + & + \\
\hline Malate & - & + & + & ND \\
\hline Mannose & - & + & + & - \\
\hline Succinate & - & + & + & + \\
\hline D-Xylose & - & + & + & - \\
\hline \multicolumn{5}{|l|}{ Enzyme activity (by API ZYM) } \\
\hline$\alpha$-Glucosidase & - & $(-)$ & + & + \\
\hline Acid phosphatase & + & $(\mathrm{w})$ & + & - \\
\hline Esterase lipase (C8) & + & $(\mathrm{w})$ & $\mathrm{w}$ & + \\
\hline Naphthol-AS-BI-phosphohydrolase & - & $(-)$ & + & - \\
\hline Valine arylamidase & - & $(-)$ & + & + \\
\hline DNA G + C (mol\%) & 65.2 & $63.0-63.1$ & 64.6 & 63 \\
\hline
\end{tabular}

extraction procedures (Table 2). The DNA G $+\mathrm{C}$ content of strain DSW $-17^{\mathrm{T}}$ was $65.2 \mathrm{~mol} \%$.

There were no distinct phenotypic, particularly chemotaxonomic, properties which differentiated strain DSW $-17^{\mathrm{T}}$ from members of the genus Jannaschia (Wagner-Döbler et al., 2003; Macián et al., 2005; Choi et al., 2006). Accordingly, it was concluded that strain DSW- $17^{\mathrm{T}}$ is a member of the genus Jannaschia. Strain DSW- $17^{\mathrm{T}}$ was distinguishable from recognized species of this genus by means of several phenotypic characteristics as listed in Table 1. Mean DNA-DNA relatedness values between strain DSW $-17^{\mathrm{T}}$ and the type strains of the three recognized species of the genus Jannaschia were 7-13\%, when their DNAs were used individually as labelled DNA probes for cross-hybridization, indicating that strain DSW$17^{\mathrm{T}}$ represents a separate species (Wayne et al., 1987). This phylogenetic distinctiveness, together with the genetic distinctiveness and differential phenotypic properties, are sufficient to designate strain DSW $-17^{\mathrm{T}}$ as a representative of the genus Jannaschia (Stackebrandt \& Goebel, 1994). Therefore, on the basis of the data presented, strain DSW$17^{\mathrm{T}}$ should be placed in the genus Jannaschia as representing a novel species, for which the name Jannaschia donghaensis sp. nov. is proposed.

\section{Description of Jannaschia donghaensis sp. nov.}

Jannaschia donghaensis (dong.ha.en'sis. N.L. fem. adj. donghaensis of Donghae, the Korean name for the East Sea of Korea, from where the organism was isolated).

Cells are Gram-negative and rod-, oval- or coccoid-shaped $(0.5-2.5 \times 0.6-5.0 \mu \mathrm{m})$. Colonies on MA are circular, raised, strong orange in colour and $1.0-1.5 \mathrm{~mm}$ in diameter after 7 days incubation at $25{ }^{\circ} \mathrm{C}$. Growth does not occur on TSA, NA or MacConkey agar. Growth occurs at 4 and $32{ }^{\circ} \mathrm{C}$, but not at $33{ }^{\circ} \mathrm{C}$. Optimal pH for growth is 


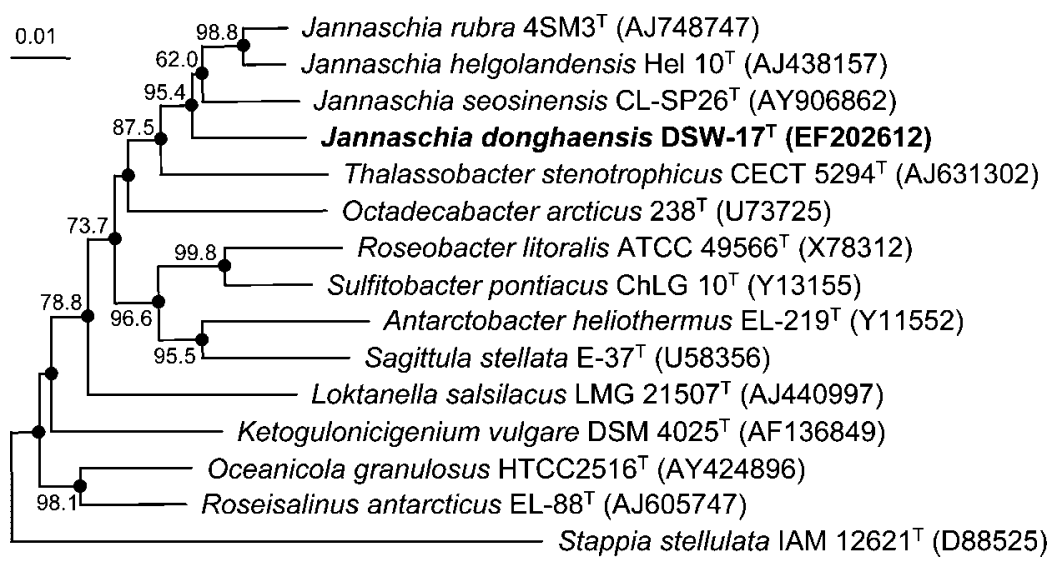

Fig. 1. Neighbour-joining phylogenetic tree based on 16S rRNA gene sequences showing the positions of Jannaschia donghaensis sp. nov. DSW $-17^{\top}$, other species of the genus Jannaschia and other related taxa. Bootstrap values (expressed as percentages of 1000 replications) of $>50 \%$ are shown at branch points. Filled circles indicate that the corresponding nodes were also recovered in the trees generated with the maximum-likelihood and maximum-parsimony algorithms. GenBank accession numbers are given in parentheses. Stappia stellulata IAM $12621^{\top}$ was used as an outgroup. Bar, 0.01 substitutions per nucleotide position. between 7.0 and 8.0; growth occurs at $\mathrm{pH} 6.0$, but not at $\mathrm{pH}$ 5.5. Growth occurs in the presence of $7 \%(\mathrm{w} / \mathrm{v}) \mathrm{NaCl}$, but not in the absence of $\mathrm{NaCl}$ or in the presence of more than $8 \%(\mathrm{w} / \mathrm{v}) \mathrm{NaCl}$. Anaerobic growth does not occur

Table 2. Cellular fatty acid content (\% of total) of Jannaschia donghaensis sp. nov. and other species of the genus Jannaschia

Strains, 1, J. donghaensis DSW-17 ${ }^{\mathrm{T}}$; 2, J. helgolandensis Hel $10^{\mathrm{T}}$ (data from Wagner-Döbler et al., 2003); 3, J. rubra CECT $5088^{\mathrm{T}}$ (Macián et al., 2005); 4, J. seosinensis CL-SP26 ${ }^{\mathrm{T}}$ (Choi et al., 2006). Fatty acids that represented $<1.0 \%$ in all strains were omitted. - , Not detected.

\begin{tabular}{|lcccc|}
\hline Fatty acid & $\mathbf{1}$ & $\mathbf{2}$ & $\mathbf{3}$ & $\mathbf{4}$ \\
\hline Straight-chain fatty acids & & & & \\
$\quad \mathrm{C}_{17: 0}$ & 1.8 & 1.0 & - & - \\
$\mathrm{C}_{18: 0}$ & 5.2 & 10.8 & 8.1 & 12.0 \\
$\mathrm{C}_{19: 0}$ & 5.9 & - & - & - \\
Unsaturated fatty acids & & & & \\
$\mathrm{C}_{12: 1}$ & - & 4.9 & - & - \\
$\mathrm{C}_{18: 1} \omega 7 c$ & 69.2 & 45.1 & 79.4 & 64.0 \\
$\mathrm{C}_{18: 3} \omega 6 c$ & - & - & - & 2.2 \\
$\mathrm{C}_{20: 1} \omega 7 c$ & 2.8 & - & - & - \\
Hydroxy fatty acids & & & & \\
$\quad \mathrm{C}_{10: 0} 3-\mathrm{OH}$ & 1.5 & 5.6 & 2.3 & 4.6 \\
$11-$ Methyl C $18: 1 \omega 7 c$ & 6.9 & 5.7 & - & - \\
10-Methyl C $19: 0$ & - & - & - & 1.9 \\
Cyclo C $19: 0 \omega 8 c$ & - & 25.1 & 5.7 & - \\
$\mathrm{C}_{14: 0} 3-\mathrm{OH} /$ iso $\mathrm{C}_{16: 1}$ & - & - & - & 3.6 \\
Summed feature $7^{*}$ & 2.9 & - & - & - \\
Unknown fatty acids & & & & \\
ECL 11.799 & 2.1 & - & 2.2 & 4.7 \\
ECL 15.273 & - & - & 1.7 & - \\
\hline
\end{tabular}

${ }^{*}$ Summed features represent groups of two or three fatty acids which could not be separated by GLC with the MIDI system. Summed feature 7 contained one or more of $\mathrm{C}_{19: 1} \omega 6 c$, cyclo $\mathrm{C}_{19: 0} \omega 10 c$ and/or unknown fatty acid (ECL 18.846). on MA or on MA supplemented with nitrate. Bacteriochlorophyll $a$ is not produced. Hypoxanthine and Tweens 20, 40 and 60 are hydrolysed, but casein, L-tyrosine and xanthine are not. $\mathrm{H}_{2} \mathrm{~S}$ and indole are not produced. Arginine dihydrolase, lysine decarboxylase, ornithine decarboxylase and tryptophan deaminase are absent. In assays with the API ZYM system, alkaline phosphatase, esterase (C4) and leucine arylamidase are present, but lipase (C14), cystine arylamidase, trypsin, $\alpha$-chymotrypsin, $\alpha$-galactosidase, $\beta$-galactosidase, $\beta$-glucuronidase, $\beta$-glucosidase, $N$-acetyl- $\beta$-glucosaminidase, $\alpha$-mannosidase and $\alpha$ fucosidase are absent. L-Arabinose, maltose, sucrose, trehalose, acetate, benzoate, pyruvate, salicin, formate and L-glutamate are not utilized. Acid is not produced from Larabinose, D-cellobiose, D-fructose, D-galactose, D-glucose, lactose, maltose, D-mannose, D-melezitose, melibiose, Draffinose, L-rhamnose, D-ribose, sucrose, trehalose, Dxylose, D-mannitol, D-sorbitol or myo-inositol. Susceptible to ampicillin, carbenicillin, cephalothin, chloramphenicol, gentamicin, kanamycin, neomycin, novobiocin, penicillin $\mathrm{G}$, polymyxin $\mathrm{B}$, streptomycin and tetracycline, but not to lincomycin or oleandomycin. The predominant ubiquinone is Q-10. The major fatty acid ( $>10 \%$ of total fatty acids) is $\mathrm{C}_{18: 1} \omega 7 \mathrm{c}$. Major polar lipids are phosphatidylcholine, phosphatidylglycerol, phosphatidylethanolamine and an unidentified glycolipid. The DNA $\mathrm{G}+\mathrm{C}$ content is $65.2 \mathrm{~mol} \%$ (determined by HPLC). Other phenotypic characteristics are given in Table 1.

The type strain, DSW $-17^{\mathrm{T}} \quad\left(=\mathrm{KCTC} \quad 12862^{\mathrm{T}}=\mathrm{JCM}\right.$ $14563^{\mathrm{T}}$ ), was isolated from seawater off Dokdo in the East Sea, Korea.

\section{Acknowledgements}

This work was supported by the 21C Frontier program of Microbial Genomics and Applications (grant MG05-0401-2-0) from the Ministry of Science and Technology (MOST) of the Republic of Korea. 


\section{References}

Adachi, M., Kanno, T., Okamoto, R., Shinozaki, A., Fujikawa-Adachi, K. \& Nishijima, T. (2004). Jannaschia cystaugens sp. nov., an Alexandrium (Dinophyceae) cyst formation-promoting bacterium from Hiroshima Bay, Japan. Int J Syst Evol Microbiol 54, 1687-1692.

Baumann, P. \& Baumann, L. (1981). The marine Gram-negative eubacteria: genera Photobacterium, Beneckea, Alteromonas, Pseudomonas, and Alcaligenes. In The Prokaryotes, pp. 1302-1331. Edited by M. P. Starr, H. Stolp, H. G. Trüper, A. Balows \& H. G. Schlegel. Berlin: Springer-Verlag.

Bruns, A., Rohde, M. \& Berthe-Corti, L. (2001). Muricauda ruestringensis gen. nov., sp. nov., a facultatively anaerobic, appendaged bacterium from German North Sea intertidal sediment. Int $J$ Syst Evol Microbiol 51, 1997-2006.

Choi, D. H., Yi, H., Chun, J. \& Cho, B. C. (2006). Jannaschia seosinensis sp. nov., isolated from hypersaline water of a solar saltern in Korea. Int J Syst Evol Microbiol 56, 45-49.

Cohen-Bazire, G., Sistrom, W. R. \& Stanier, R. Y. (1957). Kinetic studies of pigment synthesis by non-sulfur purple bacteria. $J$ Cell Physiol 49, 25-68.

Cowan, S. T. \& Steel, K. J. (1965). Manual for the Identification of Medical Bacteria. London: Cambridge University Press.

Ezaki, T., Hashimoto, Y. \& Yabuuchi, E. (1989). Fluorometric deoxyribonucleic acid-deoxyribonucleic acid hybridization in microdilution wells as an alternative to membrane filter hybridization in which radioisotopes are used to determine genetic relatedness among bacterial strains. Int J Syst Bacteriol 39, 224-229.

Komagata, K. \& Suzuki, K. (1987). Lipids and cell-wall analysis in bacterial systematics. Methods Microbiol 19, 161-207.

Lanyi, B. (1987). Classical and rapid identification methods for medically important bacteria. Methods Microbiol 19, 1-67.

Leifson, E. (1963). Determination of carbohydrate metabolism of marine bacteria. J Bacteriol 85, 1183-1184.

Macián, M. C., Arahal, D. R., Garay, E., Ludwig, W., Schleifer, K. H. \& Pujalte, M. J. (2005). Jannaschia rubra sp. nov., a red-pigmented bacterium isolated from sea water. Int J Syst Evol Microbiol 55, 649653.

Minnikin, D. E., O'Donnell, A. G., Goodfellow, M., Alderson, G., Athalye, M., Schaal, A. \& Parlett, J. H. (1984). An integrated procedure for the extraction of bacterial isoprenoid quinones and polar lipids. J Microbiol Methods 2, 233-241.
Pujalte, M. J., Macián, M. C., Arahal, D. R. \& Garay, E. (2005). Thalassobacter stenotrophicus Macián et al. 2005 is a later synonym of Jannaschia cystaugens Adachi et al. 2004, with emended description of the genus Thalassobacter. Int J Syst Evol Microbiol 55, 1959-1963.

Sasser, M. (1990). Identification of bacteria by gas chromatography of cellular fatty acids, MIDI Technical Note 101. Newark, DE: MIDI Inc.

Stackebrandt, E. \& Goebel, B. M. (1994). Taxonomic note: a place for DNA-DNA reassociation and $16 \mathrm{~S}$ rRNA sequence analysis in the present species definition in bacteriology. Int J Syst Bacteriol 44, 846849.

Staley, J. T. (1968). Prosthecomicrobium and Ancalomicrobium: new prosthecate freshwater bacteria. J Bacteriol 95, 1921-1942.

Tamaoka, J. \& Komagata, K. (1984). Determination of DNA base composition by reversed-phase high-performance liquid chromatography. FEMS Microbiol Lett 25, 125-128.

Wagner-Döbler, I., Rheims, H., Felske, A., Pukall, R. \& Tindall, B. J. (2003). Jannaschia helgolandensis gen. nov., sp. nov., a novel abundant member of the marine Roseobacter clade from the North Sea. Int J Syst Evol Microbiol 53, 731-738.

Wayne, L. G., Brenner, D. J., Colwell, R. R., Grimont, P. A. D., Kandler, O., Krichevsky, M. I., Moore, L. H., Moore, W. E. C., Murray, R. G. E. \& other authors (1987). International Committee on Systematic Bacteriology. Report of the ad hoc committee on reconciliation of approaches to bacterial systematics. Int J Syst Bacteriol 37, 463-464.

Yoon, J.-H., Kim, H., Kim, S.-B., Kim, H.-J., Kim, W. Y., Lee, S. T., Goodfellow, M. \& Park, Y.-H. (1996). Identification of Saccharomonospora strains by the use of genomic DNA fragments and rRNA gene probes. Int J Syst Bacteriol 46, 502-505.

Yoon, J.-H., Lee, S. T. \& Park, Y.-H. (1998). Inter- and intraspecific phylogenetic analysis of the genus Nocardioides and related taxa based on 16S rRNA gene sequences. Int J Syst Bacteriol 48, 187-194.

Yoon, J.-H., Kang, K. H. \& Park, Y.-H. (2003). Psychrobacter jeotgali sp. nov., isolated from jeotgal, a traditional Korean fermented seafood. Int J Syst Evol Microbiol 53, 449-454.

Yurkov, V., Stackebrandt, E., Holmes, A., Fuerst, J. A., Hugenholtz, P., Golecki, J., Gad'on, N., Gorlenko, V. M., Kompantseva, E. I. \& Drews, G. (1994). Phylogenetic positions of novel aerobic, bacteriochlorophyll a-containing bacteria and description of Roseococcus thiosulfatophilus gen. nov., sp. nov., Erythromicrobium ramosum gen. nov., sp. nov., and Erythrobacter litoralis sp. nov. Int J Syst Bacteriol 44, 427-434. 